\title{
DEPOPULATION IN NORTHERN MONTENEGRO CAUSES AND CONSEQUENCES
}

DOI: http://dx.doi.org/10.18509/GBP.2015.31

UDC: 314.116-022.252(497.16-17),,1961/2011“6

\section{Dragica Mijanović}

Study program of Geography, Faculty of Philosophy in Niksic, Montenegro

\begin{abstract}
In the second half of the twentieth century the biggest economic development in Montenegro begins thanks to intensive industrialization, which, due to the need for labor force has launched strong migration movements towards both the urban areas, and the central region, where industrial buildings were the most concentrated, and some time later towards the coastal region, which due to the development of tourism, has become attractive for immigration processes. At the same time, agriculture that was the most important economic activity of the northern region was neglected, which caused the mass deagrarization and emigration, starting from the 60 s of the last century, which still continues. In the 80s of the last century the process of depopulation began in some parts, and later it affected the entire northern region.

In this paper, using statistical, analytical, synthetic and cartographic methods, pointed out will be the causes, intensity and consequences of depopulation of this region, which occupies more than half of the country's territory, and in which today lives less than a sixsth of the population of Montenegro.
\end{abstract}

Keywords: industrialization, migrations, deagrarization, depopulation

\section{INTRODUCTION}

The northern region of Montenegro administratively consists of 13 municipalities ${ }^{8}$, it covers an area of $7304 \mathrm{~km}^{2}$, or $52.9 \%$ of the area of Montenegro. According to the results of thecensus of 2011 in northern region lived 177793 inhabitants, or $13.9 \%$ of the state population. Average population density is 24.3 inhabitants per $\mathrm{km}^{2}$, and it is significantly below the population density of Montenegro (45.3 inhabitants per $\mathrm{km}^{2}$ ), while in the '60s, when intensive industrialization in Montenegro began, in this region lived 210978 inhabitants, or $46.2 \%$ of the population of Montenegro. The average population density was 38.1 inhabitants per $\mathrm{km}^{2}$.

Economic development of Montenegro after the Second World War took place in the former Federal Federative Republic of Yugoslavia, except that Montenegro had its own specifics given that it was one of the least developed republics of the former state and it also had the unfavorable economic structure of the population. Development proceeded

\footnotetext{
${ }^{8}$ Municipalities that belong to this region are: Andrijevica, Berane, Bijelo Polje, Gusinje, Žabljak, Kolašin, Mojkovac, Petnjica, Plav, Plužine, Pljevlja, Rožaje and Šavnik.
} 
in the direction of the dominant development of heavy industry, traffic somewhat, while other branches of industry significantly lagged behind in development, which was, again, a specificity of Montenegro [3; 56]. Along with the development of industry and the growth of its social product, social product of agriculture declined, it was more and more becoming marginalized activity, which had far-reaching consequences for the demographic development of the northern region in which in the 60 s of last century it was the main activity for $65 \%$ of the population [1;224].

Through the analysis of the movement of population, migration characteristics, gender and age structure, changes in population size of rural and urban settlements in the region and municipalities, the paper will indicate the extent of depopulation, its causes and consequences.

\section{DEMOGRAPHIC MOVEMENTS TILL 80'S OF THE XX CENTURY AND THE BEGINNING OF DEPOPULATION}

In the second half of the twentieth century this region was affected by the process of industrialization as well, although it in terms of volume, tempo, and the structure it was not as in had been in the central region. The largest number of industrial capacities, which are mostly located in urban areas of the region (Berane, Bijelo Polje, Pljevlja, Kolasin, Podgorica, Plav and Rožaje) were oriented to primary production, which in relation to the manufacturing branches was less productive and efficient [4;84]. This was the main reason why all the industrial capacities during the transition period, which started in the 90s of the last century, had lost the race in the market, which caused a constant decrease in the number of employees, work with reduced capacity and finaly it led to the closing of the largest number of the capacities.

The period from the 60 s to the 80 s of the last century was the most economically significant for the northern region. Changes in the economic development of the northern region directly affected demographic development. The growth of industrial production and its share in social production of Montenegro was followed by the growth of population in the region for 3708 inhabitants. Regardless of economic growth, it should be noted that the migration in this region has always been strong and that the population growth was solely a consequence of the relatively high rate of population growth, which in the mid 60s totaled $16.4 \%$ [10]. and which managed at the regional level to compensate emigration, which was not the case with some municipalities (municipalities: Pluzine, Savnik, Zabljak, Andrijevica, Kolasin and Pljevlja undergone depopulation in the period 1961-1981- Table 1).

The population of the region in the 60 s was young with $48.4 \%$ of the young aged and $11.8 \%$ of the old aged population. The participation of young population in municipalities ranged from $43.5 \%$ in Kolasin to $53.5 \%$ in the Rožaje, while the share of old population ranged from $6.1 \%$ in Rožaje to $12.9 \%$ in Šavnik [2; 68]. Although in the 80s the region had young population (39.9\% of young and $11.8 \%$ of the old population) in some municipalities, where emigration was more pronounced the process of aging began. The municipalities of Durmitor area (Šavnik, Plužine and Zabljak) were in particular 
endangered - the participation of the old population increased significantly and participation of young population declined. On the threshold of old age population were the municipality of Kolasin and Podgorica as well. [1;220].

Table 1. Changes of the number of inhabitants of the northern region and municipalities in the period 1961-2011.

\begin{tabular}{|l|r|r|r|r|r|}
\hline & \multicolumn{1}{|c|}{1961} & 1981 & \multicolumn{1}{c|}{$\begin{array}{c}\text { Index } \\
1981 / 1961\end{array}$} & 2011 & \multicolumn{1}{c|}{$\begin{array}{c}\text { Index } \\
2011 / 1981\end{array}$} \\
\hline Andrijevica & 9792 & 7712 & 78,8 & 5071 & 65,8 \\
Berane & 24124 & 31270 & 129,6 & 28488 & 91,1 \\
Bijelo Polje & 38740 & 41281 & 106,6 & 46056 & 111,6 \\
Gusinje & 7427 & 7842 & 105,6 & 4027 & 51,4 \\
Kolašin & 14882 & 12669 & 85,1 & 8376 & 66,1 \\
Mojkovac & 8832 & 10753 & 121,8 & 8622 & 80,2 \\
Petnjica & 10156 & 10790 & 106,2 & 5482 & 50,8 \\
Plav & 11486 & 11718 & 102,0 & 9081 & 77,5 \\
Pljevlja & 46370 & 43323 & 93,4 & 30786 & 71,1 \\
Plužine & 9164 & 6254 & 68,2 & 3201 & 51,2 \\
Rožaje & 14700 & 20227 & 137,6 & 22964 & 113,5 \\
Šavnik & 7589 & 5620 & 74,1 & 2070 & 36,8 \\
Žabljak & 7716 & 5227 & 67,7 & 3569 & 68,3 \\
NOTHERN REGION & 210978 & 214686 & 101,8 & 177793 & 82,8 \\
\hline
\end{tabular}

Source of data: [5] Monstat: Comparative overview of the number of inhabitants from 1948 to 2003, vol. 9 - Data by settlements, Podgorica, 2005; [7] Monstat: The first results of the census, Podgorica, 2011.

Based on the analysis of total and natural movement we have obtained data on the mechanical ${ }^{9}$ movement of the population of the northern region in the period from the 60 s to the 80s. When we talk about population growth, the region got 47099 inhabitants, the actual population growth amounted to 3708 , i.e. thanks to emigration the region had lost 43391 inhabitants. During this period, no municipality in the region had a positive migration balance; emigration was especially expressed in Durmitor area municipalities: Zabljak, Pluzine, Savnik, then Bijelo Polje and Pljevlja - Table 2.

The best indicators of depopulation of the region are the changes in the average size of villages in the period 1961-1981, because the depopulation first started in the villages. The average size of villages in the northern region declined from 377 to 349 inhabitants. The greatest depopulation had the villages of Andrijevica, then Pluzine and Zabljak municipalities. In this period, only villages in the municipality of Berane, Rožaje and Gusinje were not affected by depopulation. The development of industry in the region strengthened the internal rural-urban migration, which, in the initial phase had positive effects because agriculture was freed of excess and cities received the lacking amount of workforce. However, over time, urban settlements in the region were fed up, but that did not stop the migration from the countryside nor advanced deagrarisation process as it was

\footnotetext{
${ }^{9}$ The migration characteristics of the population were made only during the census of 2003 , so we got migratory balance by calculating difference between the total population movements and population growth, which we calculated according to the population growth rates in the given periods.
} 
indicated by the fact that in 1981 in the region there was only $23.2 \%$ of the agricultural population $[1 ; 224]$. In contrast to declining population size of villages, urban settlements in all municipalities in the region faced with the population growth in this period, especially Berane, Pljevlja and Bijelo Polje, which were the largest when we talk about population, and most developed when we talk about industry $[2 ; 116]$.

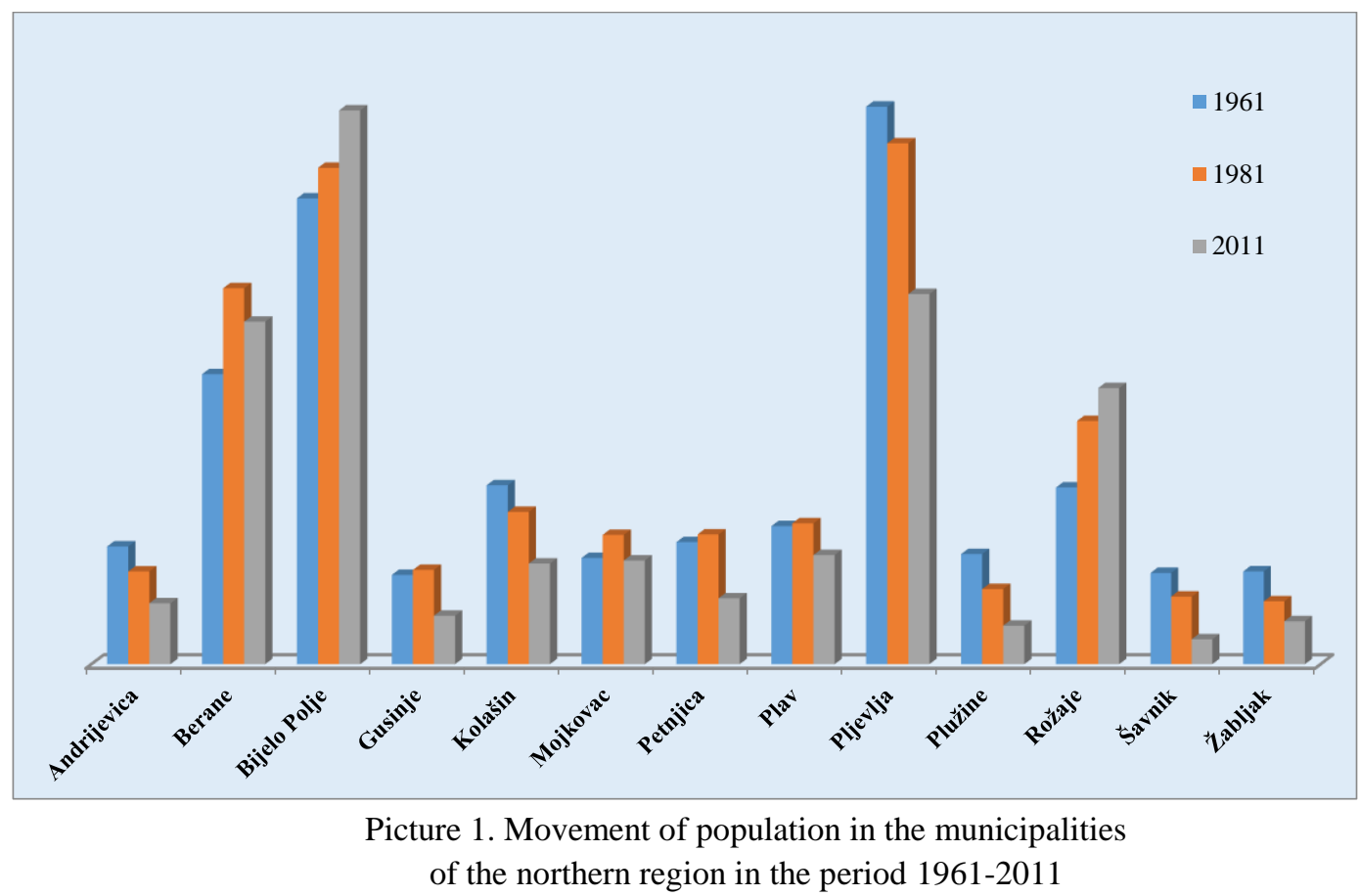

In addition to the urban areas of the northern region, a large number of migrants went to other regions of Montenegro - central and coastal, and a considerable part of it, especially from the northeastern part (municipalities of Bijelo Polje, Plav and Rožaje) went beyond the borders of Montenegro. The reasons for the strong emigration from the area of the region should be sought in the neglect of agricultural production, which was, as pointed out, the leading economic sector. Agriculture was based on private land and it was of extensive type, so it easy lost pace with industrialization, which dragged off workforce from the countryside. Given that industrial capacities in the region were quickly filled with workforce, migration was directed towards the industrially much stronger central region, or towards the seaside in which intensive development of tourism began, in which workforce lacked. In this way, the northern region was freed of excess workforce, because it was the most vital region in terms of natural population movements. This period could be called the first phase of depopulation. It is characterized by significant depopulation in rural areas of Durmitor, then in the municipaliy of Andrijevica and the beginning of depopulation in Pljevlja and Kolasin municipalities. In other municipalities, only in the following period population decline was significant. 


\section{DEMOGRAPHIC MOVEMENTS AFTER 8OS OF XX CENTURY - THE SECOND PHASE OF DEPOPULATION}

Deagrarisation process of the 80 s of XX century was strengthened in the northern region, emigration also strenghtend, natural growth became negative (- $2.8 \%$ ) $[9 ; 225]$, so all resulted in a significant decline of population - 36,893 untill 2011. In the period 19812011 only the municipalities of Bijelo Polje and Rožaje had population growth, all the others decline. The largest decline was recorded in the municipalities of Šavnik, Plužine, Petnjica, Gusinje and Zabljak. The participation of young population in the total population of the region declined to $26.4 \%$, while the old increased to $21 \%$, which indicated to a ripe old age population [8]. In the deep demographic age is the population of municipalities: Andrijevica, Kolasin, Mojkovac, and in the deepest demographic age population of the municipalities of Podgorica, Šavnik, Plužine and Zabljak.

In the period 1981-2011 when it is up to population growth, the region got 23378 inhabitants, but, given that it had a decline of population for 36893 , it means that in this period from the region emigrated 60271 of inhabitants. According to these data it could be seen how much depopulation strengthened. Particularly high rates of emigration had municipalities of Rožaje, Pljevlja, Bijelo Polje and Berane - Table 2. Average size of villages in the region was further reduced to 227 inhabitants. With the exception of the municipality of Berane, where the average size increased slightly, in all other municipalities of the region the average size of villages has declined significantly, it was the lowest in the municipalities of Plužine 44 inhabitants, Savnik 61 inhabitants, Zabljak 68 inhabitants - Picture 2. Based on the analysis of these several parameters and their comparison we can see that the depopulation today engulfed the entire northern region. This is supported by the fact that according to the results of the agricultural census of 2010 in it only $14.3 \%$ of the agricultural population were presented (excluding municipalities of Šavnik and Andrijevica all others had below $20 \%$ of the agricultural population) [6].

Table 2. Migration characteristics of the population

of northern region and municipalities for the period 1961-2011

\begin{tabular}{|l|l|r|r|}
\hline \multirow{2}{*}{ Municipality $^{\mathbf{1 0}}$} & & $\begin{array}{l}\mathbf{1 9 6 1 -} \\
\mathbf{1 9 8 1}\end{array}$ & $\begin{array}{l}\text { 1981- } \\
\mathbf{2 0 1 1}\end{array}$ \\
\hline \multirow{4}{*}{ Andrijevica } & Total movement & -2080 & -1997 \\
\cline { 2 - 4 } & Natural growth & & -204 \\
\cline { 2 - 4 } & Migrational balance & 0 & -464 \\
\hline \multirow{3}{*}{ Berane } & Total movement & 7780 & -855 \\
\cline { 2 - 4 } & Natural growth & 12812 & 10336 \\
\cline { 2 - 4 } & Migrational balance & -5032 & -11191 \\
\hline \multirow{2}{*}{ Bijelo Polje } & Total movement & 8983 & -2175 \\
\cline { 2 - 4 } & Natural growth & 19928 & 12524 \\
\hline
\end{tabular}

\footnotetext{
${ }^{10}$ The municipalities Gusinje i Petnjica are new formed (from 2013), those were a part of the municipalities Berane and Plav - for them there are no data on natural growth and because of thet they are not included in the table.
} 


\begin{tabular}{|c|c|c|c|}
\hline & Migrational balance & -10945 & -14699 \\
\hline \multirow{3}{*}{ Žabljak } & Total movement & -1338 & -1593 \\
\hline & Natural growth & 1217 & 43 \\
\hline & Migrational balance & -2555 & -1636 \\
\hline \multirow{3}{*}{ Kolašin } & Total movement & -2226 & -4142 \\
\hline & Natural growth & 2938 & 562 \\
\hline & Migrational balance & -5164 & -4704 \\
\hline \multirow{3}{*}{ Mojkovac } & Total movement & 1921 & -1870 \\
\hline & Natural growth & 3322 & 1887 \\
\hline & Migrational balance & -1401 & -3757 \\
\hline \multirow{3}{*}{ Plav } & Total movement & 647 & 1744 \\
\hline & Natural growth & 7018 & 4217 \\
\hline & Migrational balance & -6371 & -2473 \\
\hline \multirow{3}{*}{ Plužine } & Total movement & -2910 & -2945 \\
\hline & Natural growth & 1695 & -63 \\
\hline & Migrational balance & -4605 & -2882 \\
\hline \multirow{3}{*}{ Pljevlja } & Total movement & -3361 & -11149 \\
\hline & Natural growth & 9955 & 2454 \\
\hline & Migrational balance & -13316 & -13603 \\
\hline \multirow{3}{*}{ Rožaje } & Total movement & 7332 & 2737 \\
\hline & Natural growth & 9110 & 20022 \\
\hline & Migrational balance & -1778 & -17285 \\
\hline \multirow{3}{*}{ Šavnik } & Total movement & -1964 & -3465 \\
\hline & Natural growth & 1026 & -326 \\
\hline & Migrational balance & -2990 & -3139 \\
\hline \multirow{3}{*}{ NOTHERN REGION } & Total movement & -9380 & -4686 \\
\hline & Natural growth & 47099 & 23378 \\
\hline & Migrational balance & -52379 & -59764 \\
\hline
\end{tabular}

Source of data: [10] Republic Statistical Office, Titograd: Vital statistics for 1961 and 1981; [5] Monstat: Comparative overview of the number of inhabitants from 1948 to 2003, vol. 9 - Data by settlements, Podgorica, 2005; [7] Monstat The first results of the census, Podgorica, 2011.

Such depopulation of the area of the northern region is caused by the period of economic transition that began in 90s. Weak competitiveness of industrial capacities of the region, which, losing the race on the domestic and foreign markets, largely stopped working had already been emphasized. Getting out from the economic uncertainty was sought outside the region, or outside the country - in any case emigration was enhanced and more comprehensive than in the previous period. It was smaller only in demographic discharged municipalities of Durmitor area, while in the others, in fact, in the 90-ies of the last century it had the highest intensity. 


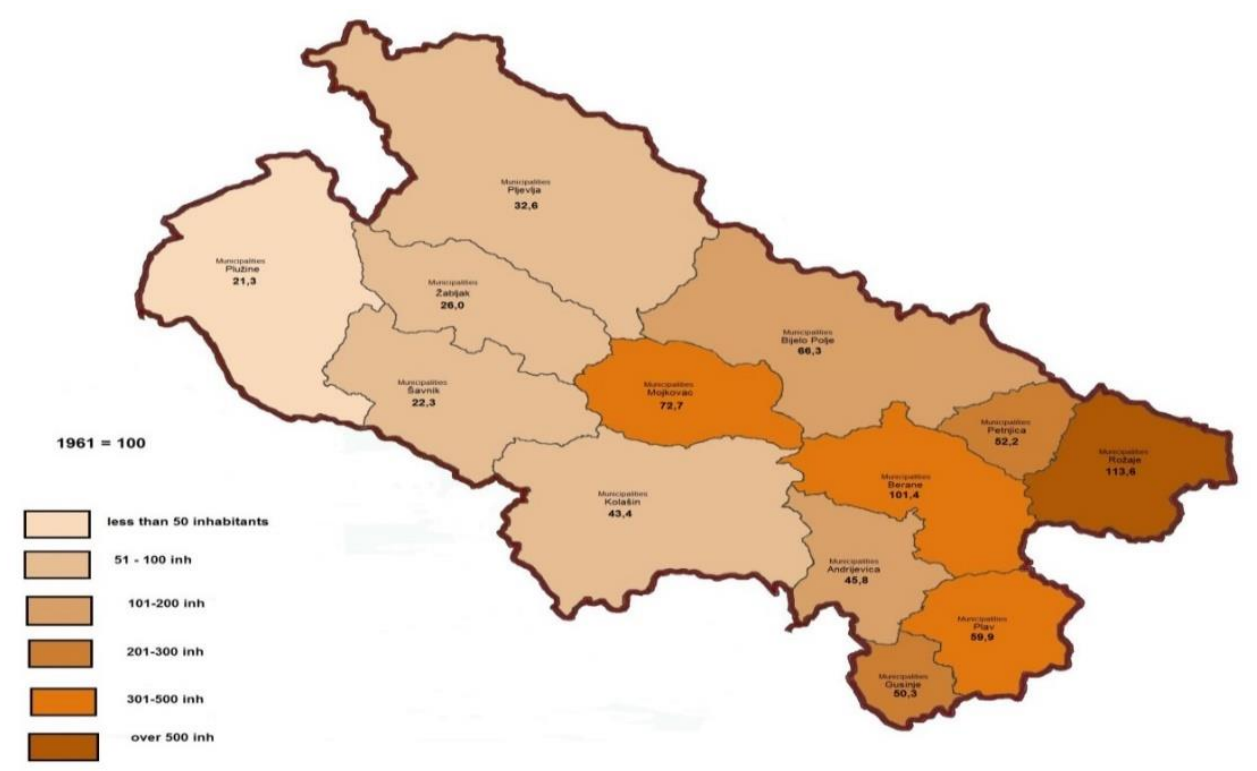

Picture 2. The average size of villages in the municipalities of the region in 2011

\section{CONCLUSION}

Depopulation in the northern region began in the second half of the twentieth century in Durmitor and Pljevlja area, but the highest intensity it had after 90s of the last century, when it affected all the municipalities in the region. Then began a period of transition of the economy, which for Montenegro was difficult, especially for the northern region. Its industrial capacities had not withstand racing on the market and were usually blow out one by one, which intensified emigration of population from the area of the region. Given that the natural population growth in the region at the beginning of XXI century was negative, the region on this basis was losing population as well, which resulted in the extreme demographic aging of the population of some municipalities. On the other hand, agricultural production, which was responsible for the development of the region, was brought to the brink of collapse due to missing and senilized workforce, poor mechanization, almost no investment and the impossibility of display products on the market and because of little number of farmers who remained.

The main demographic problem that requires urgent resolution of this region is a constant emigration of young people, especially the educated population that leaves the region because of weak opportunities of the economy for employment, and thus for retaining of the staff. If the State do not take urgent measures and adequate demographic and population policy to revive agricultural production and strengthen the economic power of the village, there will be a complete depopulation and demographic extinction of rural settlements in this region. 


\section{REFERENCES}

[1] Bakić R., Mijanović D: The population of Montenegro in the second half of the XX century, Nikšić 2008; p. 1-232.

[2] Bakić R., Mijanović D., Doderović M: Demographic movements, part of the subproject Population Aspects; Project Montenegro in the XXI century in the era of competitiveness, Podgorica 2010; p. 29-168.

[3] Kostić M: Economic development and demographic changes, Proceeding of the papers from the scientific congres Demographic Movements and Population Problems, CANU, Podgorica, 2006; p. 47-67.

[4] Radulović J: Economic development and spatial distribution of population in Montenegro, Proceeding of the papers from the scientific congres Demographic Movements and Population Problems, CANU, Podgorica, 2006; p. 69-91.

[5] Monstat - The Statistical Office of Montenegro: Comparative overview of number of inhabitants from 1948 to 2003. g., vol. 9 - Data by settlements, Podgorica, 2005.

[6] Monstat - The Statistical Office of Montenegro: first results of the census of agriculture, Podgorica, 2010.

[7] Monsta - The Statistical Office of Montenegro: The first results of the census, Podgorica, 2011.

[8] Monstat - The Statistical Office of Montenegro: tables of the census 2011: Table O20 - average age; Table N4 - age and sex;

[9] Monstat- The Statistical Office of Montenegro: Statistical Yearbook for 2014.

[10] Republic Institute for Statistics, Beograd: Vital statistics for 1961 and 1981 year. 